\title{
Polymorphic microsatellites of analysis in cultivars of taro
}

\author{
Raquel SC Nunes ${ }^{1}$; Fernanda R Pinhati ${ }^{1}$; Luciana P Golinelli'; Tiyoko Nair H Rebouças²; Vânia Margaret \\ F Paschoalin ${ }^{1}$; Joab T da Silva ${ }^{1}$ \\ ${ }^{1}$ UFRJ, Inst. Química, Av. Athos da Silveira Ramos 149, Bl. A sl. 545, Cidade Universitária, 21949-909 Rio de Janeiro-RJ; \\ raquelcasaes@iq.ufrj.br; ${ }^{2}$ UESB, Depto. Fitotecnia e Zootecnia, 45083-900, Vitória da Conquista-BA
}

\begin{abstract}
Taro (Colocasia esculenta) is a tuberous plant belonging to the Araceae family whose tuber is the $14^{\text {th }}$ most consumed food crop in the world. Characterized as an unconventional vegetable, taro is grown in Brazil as a subsistence crop, but in recent years began to gain commercial importance, especially in the states of Espirito Santo, Minas Gerais and Rio de Janeiro. To avoid loss of genetic diversity of the local varieties traditionally grown in Brazil a core collection for taro germplasm has been developed by the Instituto Capixaba de Pesquisa, Assistência Técnica e Extensão Rural do estado do Espirito Santo (Incaper). The aim of this study was to perform a molecular characterization of the seven regional core collections. Genetic diversity of the cultivars was investigated by using SSR (Simple Sequence Repeats) polymorphisms, in seven loci (Xuqtem55, Xuqtem73, Xuqtem84, Xuqtem88, Xuqtem91, Xuqtem97 and Xuqtem110). Genetic diversity of the cultivars, based on the seven microsatellite alleles, was evaluated by using the software GelCompar II, showed that the loci Xuqtem 73, Xuqtem 88 and Xuqtem 110 were the most informative, featuring 7, 10 and 8 alleles, respectively, a percentage of cultivars with polymorphic alleles of 85,57 and $100 \%$ and identical PIC of 0.91. Based on Xuqtem110 locus analysis, the seven cultivars were grouped in two clusters. Chinês Regional Incaper cultivar was originated from Chinês cultivar which originated the São Bento cultivar, corroborating previous results. Macaquinho and Chinês cultivars were shown to be the primitive ones originating the allelic collections found in the states of Mato Grosso do Sul and Espirito Santo.
\end{abstract}

Keywords: Colocasia esculenta, germplasm, cultivars.

\section{RESUMO}

Análise polimórfica por microssatélites em cultivares de taro

O taro (Colocasia esculenta) é uma hortaliça da família Araceae cujo rizoma é o décimo quarto alimento vegetal mais consumido no mundo. Caracterizado como uma hortaliça não convencional, o taro é cultivado no Brasil como uma cultura de subsistência, mas nos últimos anos começou a ser cultivado comercialmente, sobretudo nos estados de Espirito Santo, Minas Gerais e Rio de Janeiro. Para evitar a perda da diversidade genética das variedades locais tradicionalmente cultivadas no Brasil é necessária a manutenção das cultivares em bancos de germoplasma. O objetivo do trabalho foi caracterizar geneticamente as cultivares do taro provenientes do banco de germoplasma do Instituto Capixaba de Pesquisa, Assistência Técnica e Extensão Rural do estado do Espirito Santo (Incaper). Foi extraído o DNA dos tecidos desidratados das amostras de taro e a diversidade genética de sete cultivares foi investigada por PCR utilizando sete pares de iniciadores que detectam polimorfismos do tipo SSR (simple sequence repeats), em sete loci (Xuqtem55, Xuqtem73, Xuqtem84, Xuqtem88, Xuqtem91, Xuqtem97 e Xuqtem110). A diversidade genética das cultivares, com base nos alelos destes microssatélites foi avaliada com o software GelCompar II. Os loci Xuqtem73, Xuqtem 88 e Xuqtem 110 foram os mais informativos, apresentando 7, 10 e 8 alelos, respectivamente, com 85,57 e $100 \%$ de cultivares com alelos polimórficos e PIC idênticos de 0,91. A análise do polimorfismo do locus Xuqtem110 permitiu o agrupamento das 7 cultivares em dois clusters com características fenotípicas semelhante e permitiu afimar que o clone Chinês originou o clone Chinês Regional Incaper, que por sua vez deu origem à variedade São Bento, corroborando dados da literatura. As cultivares Macaquinho e Chinês podem ser consideradas enraizadoras dos loci analisados, indicando que estas cultivares podem ter originado as cultivares das regiões dos estados de Mato Grosso do Sul e do Espirito Santo.

Palavras-chave: Colocasia esculenta, germoplasma, cultivares.

(Recebido para publicação em 11 de julho de 2011; aceito em 2 de fevereiro de 2012) (Received on July 11, 2011; accepted on February 2, 2012)

$\mathrm{F}$ resh vegetable cultivation has decreased significantly in various regions of Brazil. Taking into account the consumption (monetary and nonmonetary acquisition) of vegetables for one Brazilian/year in kilograms ingested in residences, it was found that there was an average reduction of $1.93 \mathrm{~kg} /$ person from 2002 and 2008. Consumption per person/year in homes was $29 \mathrm{~kg}$ in 2002 , but $27.08 \mathrm{~kg}$ in 2008. This fall was greatest in the Southeastern region, where per capita intake fell by $4.43 \mathrm{~kg} /$ person/year, totaling $28 \mathrm{~kg} /$ person in 2008.

This reduction in consumption was observed in both rural and urban areas and in all social classes as a result of globalization and the increasing use of industrialized foods. As a consequence, significant changes in the feeding pattern of the Brazilians have been observed, with a loss of cultural identity, contributing to food safety and nutritional problems. Actions that encourage vegetable consumption, especially local varieties, are important to perpetuate good eating habits. Further, the importance of valorizing the social and cultural patrimony of the Brazilian people should be emphasized (Eyzaguirre et al., 1999; Madeira et al., 2008). 
Nonconventional vegetables are those with limited distribution, restricted to certain localities or regions that have a great influence on the nutrition and culture of traditional populations. They are also species that are not organized in formal productive chains, unlike conventional vegetables (such as potato, tomato, cabbage and lettuce) (FAO, 2010).

Non-conventional vegetables are cultivated in Brazil predominantly by family farmers in traditional populations for consumption by the family itself, that pass on the knowledge of cultivation and consumption of these plants from generation to generation. Thus, maintaining the cultivars is difficult, especially because there are no studies on their cultivation and no encouragement to use these nonconventional vegetables (Diegues \& Arruda, 2001).

The taro (Colocasia esculenta), mistakenly called yam, is a non conventional rhizome, a herbaceous species of the Liliatae class, Araceae family. It is a very robust vegetable that can grow taller than $1.18 \mathrm{~m}$, greatly sought after as a food vegetable because of its big tuberous rhizomes also known as tubercles (Madeira et al., 2008). This plant is grown in tropical and subtropical climates and can develop under conditions that are adverse for other species, such as poor soils, with excess water, shading or submitted to climatic stress. Its cultivation is considered cheap because it is a rustic plant and not very demanding for soil fertility. Furthermore, it presents high yield per area unit, is easy to conserve, has a high nutritional value and is insect and disease resistant (Wang et al., 1983; Zárate et al., 2006a, 2006b).

The taro is a vegetable that has been little studied in Brazil for its diversity and genetic functionality due to its limited consumption and commercialization. Studies are needed to preserve the different species, preventing their extinction. Taro cultivars have appeared because of vegetative mutations of the species over the years.

According to Brazilian legislation on seeds and cultivars (Law n. 10.711, 5/08/03), defined as a local, traditional cultivar "the developed variety adapted or produced by family farmers, settled by agrarian reform or indigenous peoples, with well determined phenotypic characteristics and recognized by the respective communities and that, by the MAPA (2010) criteria also considering the social, cultural and environmental descriptors, is not characterized as substantially similar to the commercial cultivars".

The best known Colocasia cultivars in Brazil, according to Puiatti (2002) are "Cem em Um", "Chinês", "Japonês", "Macaquinho" and "São Bento". The incentive to cultivate and propagate the cultivars stimulates maintenance and conservation of the species produced preventing genetic losses by inflorescence or microbial deterioration and adds knowledge on the value and nutritional function. Genetic studies identify morphological varieties classifying them as cultivars from knowledge of the genetic divergence among them.

Brazil has a considerable territorial extension, with wide climatic diversity, that favors genetic diversity in wild vegetables, with the creation of local varieties that require studies on propagation and consumption. The way of conserving genetic resources adopted by several vegetable breeding programs (Tarogen, 2001; Tansao, 2000) is ex situ conservation in germplasm banks (Nass et al., 2001). In the last 10 years, techniques that distinguish directly at DNA level have permitted access to genetic variability inside the genetic pool of cultivated species and had identified the diversity available in germplasm banks. Microsatellite-type markers (SSR) have high polymorphism information content and are ideal to identify and discriminate genotypes. The objective of the present study was to characterize polymorphically the taro cultivars from the state of Espirito Santo by analyzing seven SSR type microsatellite markers present in the Colocasia esculenta nuclear genome, assessing the intra-specific diversity and the appearance of new cultivars. Previous studies showed that analysis of the genetic diversity using this type of marker presents satisfactory results (Kreike et al., 2004; Excoffier et al.,
2005; Sardos et al., 2011), and they have been used to genetically characterize collections of taro cultivars from the islands of Papua New Guinea, Solomon Islands, Vanuatu, New Caledonia, Fiji, Palau, Niue, Tonga, Samoa and Cook Islands, all located in the Pacific ocean (Singh et al., 2007).

\section{MATERIAL AND METHODS}

Sample collection - Seven taro cultivars, Macaquinho (UFMS), Chinês (UFMS), Japonês (UFMS), Branco (UFMS), Chinês R, Cem em Um (UFMS) and São Bento were obtained from the germplasm bank of the state of Espirito Santo (Incaper). Rhizome samples were dehydrated in a chamber at $70^{\circ} \mathrm{C}$ for four to five days and taken to the LAABBM (Laboratório de Análises Avançadas em Bioquímica e Biologia Molecular) at the Federal University of Rio de Janeiro.

DNA extraction from the cultivars The DNA was extracted using the DNeasy Plant Mini kit (Quiagen), following the manufacturer's recommendation. The purified DNA was quantified using the Quibit fluorimeter (Invitrogen) and the Kit HS DNA (Invitrogen) reagents, following the technical recommendation by the manufacturer.

Amplification of the DNA allele fragments - Seven primers were used to amplify the DNA (Table 1) that amplified SSR (simple sequence repeat) type polymorphisms (Mace \& Godwin, 2002; Singh et al., 2007). PCR was carried out in a MyCicler (BioRad) thermocycler, and the reaction mixture contained $25 \mathrm{ng}$ DNA, $0.2 \mathrm{nM}$ of each oligonucleotide primer (pair), $0.1 \mathrm{mM}$ of each dNTP, $2.5 \mathrm{mM} \mathrm{MgCl}$, 0.5 unit Taq DNA polymerase (Promega), in a $25 \mu \mathrm{L}$ final volume. The amplification reaction consisted of an initial denaturation step $\left(94^{\circ} \mathrm{C}\right.$ for $5 \mathrm{~min}$ ), followed by 35 amplification cycles (denaturation at $94^{\circ} \mathrm{C}$ for $30 \mathrm{sec}$, annealing, ranging from 62 to $66^{\circ} \mathrm{C}$ for $1 \mathrm{~min}$ and extension at $72^{\circ} \mathrm{C}$ for $2 \mathrm{~min}$ ) and a final extension step at $72^{\circ} \mathrm{C}$ for $10 \mathrm{~min}$.

Detecting polymorphic fragments in polyacrylamide gel - To analyze the DNA amplified fragments, the 
Table 1. Changes in the amplification of taro SSR locus of Colocasia esculenta: annealing temperature and number of cycles (modificações nas condições de amplificação do locus SSR de Colocasia esculenta: temperatura de anelamento e número de ciclos). Rio de Janeiro, UFRJ, 2011.

\begin{tabular}{|c|c|c|c|c|}
\hline SSR locus & $\begin{array}{l}\text { descripting } \\
\text { author }\end{array}$ & $\begin{array}{l}\text { Annealing } \\
\text { temperature }\end{array}$ & $\begin{array}{c}\text { Cycles } \\
\left(\mathbf{n}^{0}\right)\end{array}$ & $\begin{array}{c}\text { Variation } \\
\text { of alleles } \\
\text { lenght (bp) }\end{array}$ \\
\hline \multirow{2}{*}{ Xuqtem55 } & Singh et al., 2007 & $65^{\circ} \mathrm{C}$ & 35 & $94-154$ \\
\hline & Casaes et al., 2011 & $65^{\circ} \mathrm{C}$ & 35 & $112-136$ \\
\hline \multirow{2}{*}{ Xuqtem73 } & Singh et al., 2007 & $66^{\circ} \mathrm{C}$ & 35 & $150-200$ \\
\hline & Casaes et al., 2011 & $66^{\circ} \mathrm{C}$ & 35 & $146-164$ \\
\hline \multirow{2}{*}{ Xuqtem84 } & Singh et al., 2007 & $65^{\circ} \mathrm{C}$ & 35 & $300-350$ \\
\hline & Casaes et al., 2011 & $65^{\circ} \mathrm{C}$ & 35 & $197-217$ \\
\hline \multirow{2}{*}{ Xuqtem 88} & Singh et al., 2007 & $64^{\circ} \mathrm{C}$ & 35 & $106-202$ \\
\hline & Casaes et al., 2011 & $62^{\circ} \mathrm{C}$ & 35 & 94-108 \\
\hline \multirow{2}{*}{ Xuqtem91 } & Singh et al., 2007 & $65^{\circ} \mathrm{C}$ & 35 & $300-350$ \\
\hline & Casaes et al, 2011 & $65^{\circ} \mathrm{C}$ & 35 & $258-262$ \\
\hline \multirow{2}{*}{ Xuqtem97 } & Singh et al., 2007 & $66^{\circ} \mathrm{C}$ & 32 & $224-382$ \\
\hline & Casaes et al., 2011 & $66^{\circ} \mathrm{C}$ & 35 & $248-256$ \\
\hline \multirow{2}{*}{ Xuqtem 110} & Singh et al., 2007 & $66^{\circ} \mathrm{C}$ & 35 & $300-400$ \\
\hline & Casaes et al., 2011 & $66^{\circ} \mathrm{C}$ & 35 & $250-287$ \\
\hline
\end{tabular}

*Singh et al., 2007; Casaes et al., 2011.

PCR products $(8 \mu \mathrm{l})$ were first mixed with $5 \mu 1$ of the denaturing solution [98\% formaldehyde, $10 \mathrm{mM}$ EDTA, $0.05 \%(\mathrm{w} / \mathrm{v})$ xylene cyanol and $0.05 \%$ bromophenol blue] and denatured at $94^{\circ} \mathrm{C}$ for $3 \mathrm{~min}$. A $12 \mu \mathrm{l}$ aliquot was applied to the polyacrylamide gel $(10 \%$ of acrylamide/bisacrylamide 19:1) and electrophoresis was carried out at $160 \mathrm{~V}$ and $80 \mathrm{~mA}$ for $1 \mathrm{~h}$ and $50 \mathrm{~min}$ (Mace et al., 2006). The size of the amplified fragments was determined by comparison with a standard of DNA fragments with low molecular weight (GeneRuler low Leader-Fermentas). At the end of the run the gel was stained for $30 \mathrm{~min}$ in a solution $10 \mu \mathrm{g} \mathrm{mL}^{-1}$ GelRed stain (BioAmerica), under constant agitation. The fragments were visualized by exposure to UV and documented using the Bio-Imaging System (BioAmerica Inc).

Analysis of the polymorphism in the DNA bands - The polymorphisms were assessed using the GelCompar II software (Applied Maths, Kortrijk, Belgium). The observed band pattern on a particular locus was registered as presence/absence of matrix.

The polymorphism percentage of the loci was calculated by hand. The polymorphism information content (PIC) was calculated for each locus to gain an estimate of the discriminatory power of the marker. For this, the allele frequency was calculated by direct counting in the gel, applying the PIC formula $=1-\Sigma \mathrm{pi}^{2}$, where $\mathrm{p} i$ is the frequency of allele $i$ in the population (Nei, 1987). The genetic similarity was estimated among the genotypes by coefficient of similarity, using the Sorensen-Dice coefficient (Dice, 1945). The clustering of the materials was analyzed by the unweighted pair group method with arithmetic mean (UPGMA) method using the GelCompar II program (Applied Maths, Kortrijk, Bélgica), following the equation $S i j=\frac{2 N i j}{N i+N j}$ where: $\mathrm{N}_{\mathrm{ij}}=$ number of locus bands present in both the genotypes $i$ and $j ; N_{i}=n$ number of bands present in genotypes $\mathrm{i}$ and $\mathrm{N}_{\mathrm{i}}=$ number of bands present in genotype $\mathrm{j}$.

\section{RESULTS AND DISCUSSION}

Polymorphism analysis in the Colocasia esculenta cultivars - Variations in the PCR conditions described previously were used to characterize the genetic diversity of the taro accessions maintained in the germplasm bank at Incaper (Table 1). The amplification of the Xuqtem 88 locus was standardized at $62^{\circ}$ because the temperature of $64^{\circ} \mathrm{C}$ used in a previous study (Singh et al., 2007) did not amplify the Xuqtem 88 locus. The Xuqtem 88 locus was amplified after 35 amplifications, because fragments were not obtained under the conditions previously reported (32 cycles, Singh et al., 2007). The size of the fragment amplified in the Xuqtem loci 55, 73, 84, $88,91,97,110$ varied using the same primer pairs used in the cultivars from Papua New Guinea, indicating genetic diversity among those species and the species analyzed.

The seven cultivars from the Incaper germplasm bank were amplified in the seven loci (Xuqtem 55, 73, 84, 88, $91,97,110)$ and the allele mean per locus, number of polymorphic alleles per locus, percentage of cultivars with polymorphic alleles were analyzed and the polymorphism information content was calculated (Table 2). Polymorphic alleles were considered to be the amplified products that were not present in most of the studied cultivars. Analysis of the amplification products showed variation from 3 to 10 alleles per locus. The percentage of cultivars with polymorphic alleles was greatest for the Xuqtem73 (85\%) and Xuqtem 110 loci, the later had $100 \%$ polymorphic alleles. The polymorphism information content (PIC) ranged from 0.75 to 0.91 , and the value of 0.91 was identical for the Xuqtem73, Xuqtem 88 and Xuqtem 110 markers. The Xuqtem84 locus presented the lowest PIC value (0.75).

The number of alleles detected by each microsatellite was on average 6.8 alleles/locus (minimum 3 and maximum 10 ), a relatively low number compared to the results of the microsatellite diversity in cassava and "choupo" (fruit tree), where an average of 7.5 and 13 alleles/locus was detected, respectively (Chavarriaga-Aguirre et al., 1998; Van der Schott et al. 2000).

The percentage of polymorphic alleles in the taro cultivars presented mean values of $51.2 \%$; the minimum 
Table 2. Polymorphism in seven Colocasia esculenta cultivars; seven genetic markers SSR (Xuqtem55; 73; 84; 88; 91; 97; 110) were used for analysis of seven cultivars (polimorfismo em cultivares de Colocasia esculenta; sete marcadores genéticos do tipo SSR (Xuqtem55; 73; 84; 88; 91; 97; 110) foram usados para análise das sete cultivares). Rio de Janeiro. UFRJ. 2011.

\begin{tabular}{lcccc}
\hline Initiator & $\begin{array}{c}\text { Average number } \\
\text { of alleles/locus }\end{array}$ & $\begin{array}{c}\text { Polymorphic } \\
\text { alleles/locus }\end{array}$ & $\begin{array}{c}\text { Cultivars with } \\
\text { polymorphic alleles (\%) }\end{array}$ & PIC* \\
\hline Xuqtem55 & 3 & 5 & 57 & 0.81 \\
Xuqtem73 & 7 & 4 & 85 & 0.91 \\
Xuqtem84 & 7 & 3 & 57 & 0.75 \\
Xuqtem88 & 10 & 4 & 57 & 0.91 \\
Xuqtem91 & 4 & 2 & 42.8 & 0.80 \\
Xuqtem97 & 5 & 2 & 42.8 & 0.80 \\
Xuqtem110 & 8 & 4 & 100 & 0.91 \\
\hline
\end{tabular}

*Polymorphism information content (conteúdo de informação de polimorfismo).

value of $42.8 \%$ was observed for the Xuqtem91 and Xuqtem97 markers and the maximum value was observed for the Xuqtem 110 marker (100\%). Compared with previous studies using microsatellites in potato and taro propagated vegetatively, lower levels of polymorphism were obtained, $33.3 \%$ and $38.4 \%$, respectively (Ashkenazi et al., 2001; Rallo et al., 2000). However, the descriptors in the present study were equivalent to others that reported $93 \%$ polymorphism among pea cultivars and $88 \%$ among coconut varieties (Van de Wiel et al., 1999).

The Xuqtem91 and Xuqtem97 loci were the least informative, with only two polymorphic alleles found. These loci presented the same polymorphism percentages in the cultivars $(42.8 \%)$ and the same PIC (0.80) (Table 2).

The low polymorphism of the Xuqtem91 locus was in line with findings by Mace \& Godwin (2002), who did not observe polymorphism for this locus in taro germplasm from the Pacific Islands.

Together, these data indicate that most of the polymorphic alleles found in the Xuqtem91 and Xuqtem97 loci were concentrated in a few cultivars.

The study of taro cultivars carried out on the Solomon Islands, using the Xuqtem97 marker, showed the presence of four alleles and 0.1547 PIC, indicating the low polymorphic content of the locus in this region. The study of the taro accessions stored in Papua New Guinea (using the same marker) presented four alleles, all polymorphic, with $80.0 \%$ polymorphism and 0.67 PIC.

The small quantity of polymorphic alleles for these loci studied in various regions of the world indicated a low mutation rate for these genetic regions.

The Xuqtem 73 , Xuqtem 88 and Xuqtem 110 loci were the most informative, showing 7, 10 and 8 alleles/ locus, respectively, plus a four-allele polymorphism, resulting in a percentage of cultivars with polymorphic alleles of 85,57 and $100 \%$, respectively, and identical PIC of 0.91 .

According to Singh et al. (2007), the Xuqtem 73 and 88 loci have PIC of 0.86 and 0.76 , respectively. These loci presented a high mutation rate in both the Papua New Guinea and Brazilian cultivars.

The polymorphism observed in the present study contributed for discriminating the Colocasia esculenta cultivars because the polymorphic alleles were frequently found among the cultivars, showing the presence of different cultivars.

Genetic similarity among taro cultivars calculated by analyzing the microsatellite polymorphism, using the GelCompar II software - Regarding genetic variability, the Xuqtem73, Xuqtem 88 and Xuqtem110 loci were the most informative and presented the highest number of alleles and greatest number of cultivars with polymorphism, confirming the data of the polymorphism analysis presented in Table 2 .

Figure 1 (A, B and C) presents the dendrogram generated by the
GelCompar II software using the SSR primers Xuqtem 73 , Xuqtem 88 and Xuqtem 110. The analyses were carried out based on the Sorensen-Dice coefficient.

The locus amplified with the Xuqtem 73 primers grouped the cultivars in two main clusters (Figure 1). The greatest number of alleles was observed in the Macaquinho UFMS (09) cultivar, while three alleles were observed in the São Bento cultivar, although these cultivars were grouped in the same main cluster. The Chinês R. cultivar grouped with the Japonês UFMS cultivar, forming a subcluster most closely related to another containing the cultivars from Mato Grosso do Sul (Branco and Cem em Um). The dendrogram formed by the Xuqtem 88 primer (Figure 1B) showed, similar to Xuqtem73, a main cluster formed by the cultivars from Mato Grosso do Sul. The greatest number of alleles (13) was observed in the Macaquinho UFMS cultivar, while the smallest number of alleles (01) was observed in the São Bento cultivar. For this locus, the Macaquinho clone can be considered the rooting clone of the phylogenetic tree constructed.

The polymorphism presented by the Xuqtem 110 locus (Figure 1C) grouped the cultivars into two clusters with similar phenotypic characteristics. The similarity among the Chinês, Chinês Regional Incaper and São Bento cultivars is well documented in the literature. The Chinês clone gave rise to the Chinês Regional Incaper clone, which in turn gave rise to the São Bento cultivar (Incaper, 2010). Thus at least this second main cluster correctly reflected the evolutionary history of the cultivars. These results indicated that the polymorphism of the Xuqtem 110 locus seemed to be an appropriate tool to analyze the genetic diversity of the taro cultivars in Brazil (Zárate et al., 2006b).

As in previous studies (Lebot et al., 2004; Sardos et al., 2011; Okpul et al., 2004), the analysis carried out in the present study showed that it was common for cultivars with similar morphological characteristics to group in the same cluster. This was the case of the cultivar from UFMS and INCAPER/ 

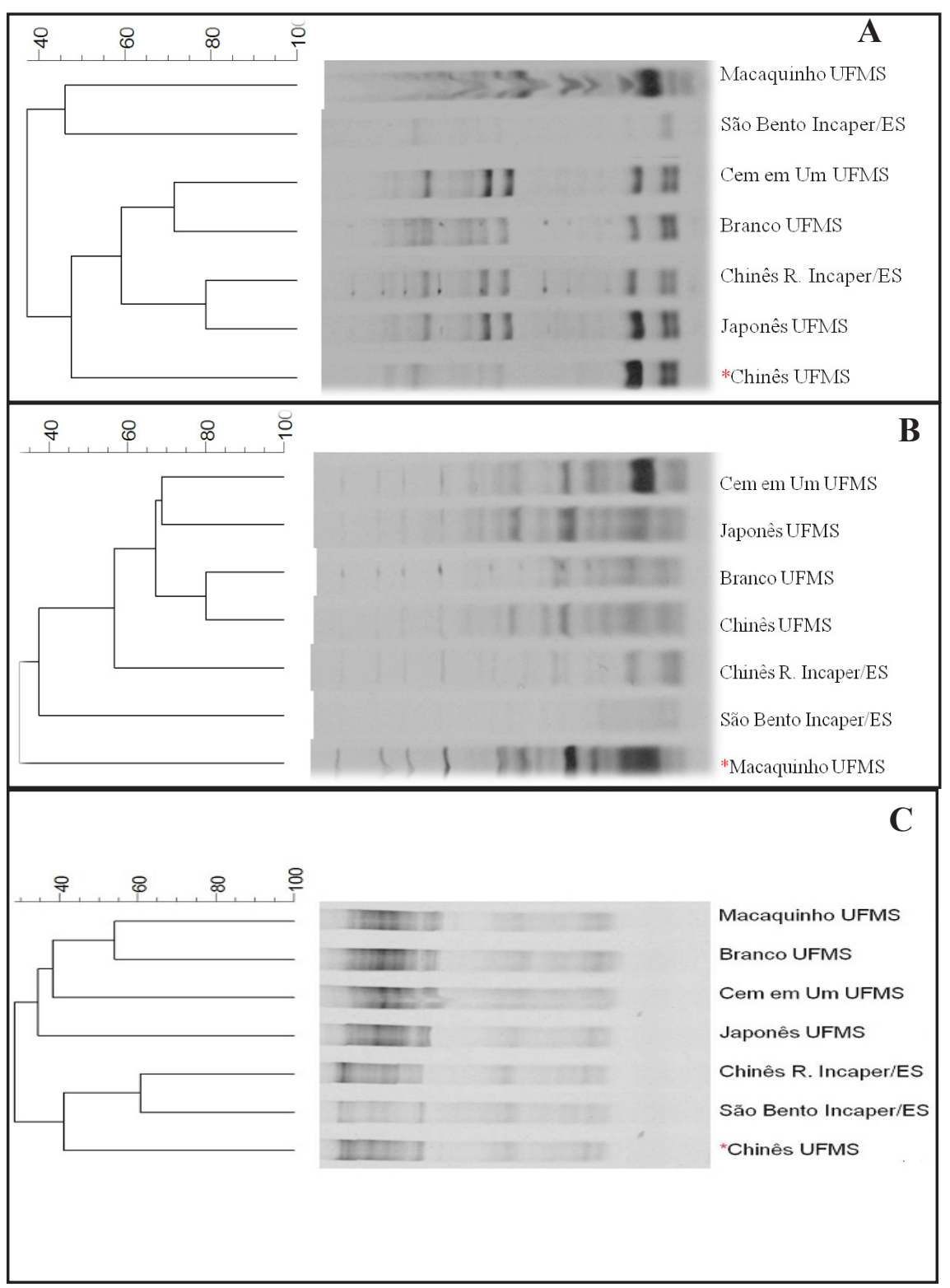

Figure 1. Analysis of genetic similarity among cultivars of Colocasia esculenta calculated by analysis of polymorphism (Panel A) Xuqtem73, (Panel B) Xuqtem 88, Panel (C) Xuqtem 110; Dendrogram generated by GelCompar II software using the Dice coefficient $[0.6 \%-1.0 \%$ Tolerance $(\mathrm{HS}=0.0 \%=0.0 \%$ ) ] and UPGMA; similarity range $0-100 \%$ (análise da similaridade genética entre as cultivares de Colocasia esculenta calculada pela análise do polimorfismo dos microssatélites SSR: (A) Xuqtem73, (B) Xuqtem 88, (C) Xuqtem 110; dendrograma gerado pelo software GelCompar II usando o coeficiente de Dice $[0,6 \%-1,0 \%$ Tolerância (HS= $0,0 \%=0,0 \%)$ e UPGMA; intervalo de similaridade 0-100\%). Rio de Janeiro, UFRJ, 2011.

ES when analyzed for the Xuqtem 110 locus polymorphism. However, the polymorphism presented by some of the loci did not always correctly represent the common phenotypic characteristics of the cultivars, as was the case of the accessions from Espirito Santo, assessed for polymorphism of the Xuqtem73, Xuqtem84 and Xuqtem97 loci.

The analysis of the taro accessions by microsatellite markers by Mace $\&$
Godwin (2002) showed that the genetic set of the numerous Pacific Islands was identical to that of Papua New Guinea, indicating that the cultivars from the Pacific islands may have been introduced in Papua New Guinea. Similarly, the present study demonstrated that the Macaquinho and Chinês cultivars could have been the primary source of analyzed loci, indicating that these cultivars could have given rise to the cultivars of the regions of the states of Mato Grosso do Sul and Espirito Santo (Figure 1). Regarding the cultivars from Espirito Santo, it is known that the São Bento clone is derived from the selection of plants of the Chinês regional clone. This information corroborated the results of the studies presented here and demonstrated the primitiveness of these clones (Vieira et al., 2005).

The polymorphism analysis obtained in the present study, from the Xuqtem73, Xuqtem 88 and Xuqtem 110 loci, contributed to discriminate the Colocasia esculenta cultivars from the germplasm bank at Incaper (ES), because the polymorphic alleles were found frequently among the cultivars so that the genetic diversity among them could be identified.

Microsatellites are used as molecular markers because of the high level of polymorphism found in their loci, so they can be used in various types of population studies, ranging from analysis of individuals to that of closely related species (Mace \& Godwin, 2002). This is possible because the complementary flanking regions to the primers are frequently conserved within the same species or among species and correlated genera, although the microsatellite regions are subject to high mutation rates (Hopkins et al., 1999).

The obtained results indicated that analysis of SSR markers can be an important tool in allele identification in the taro collections in the state of Espirito Santo. Together the morphological differences observed in the Colocasia esculenta varieties and their genetic divergence allowed them to be classified as different cultivars. The use of these microsatellites should be considered in studies to determine the diversity within the Brazilian Colocasia esculenta cultivars.

\section{ACKNOWLEDGEMENTS}

The authors thank the Carlos Chagas Filho Research Support Foundation of Rio de Janeiro state (FAPERJ) for funding and the study grant to Raquel Soares Casaes Nunes. They also thank researcher Carlos Alberto Simões do Carmo for making the INCAPER 
Colocasia esculenta cultivars available.

\section{REFERENCES}

ASHKENAZI V; CHANI E; LAVI U; LEVY D; HILLEL J; VEILLEUX RE. 2001. Development of microsatellite markers in potato and their use in phylogenetic and fingerprinting analyses. Genome 44: 50-62.

CASAES RS. 2011. Caracterização Genética de Cultivares de Taro (Colocasia esculenta (L)Schott) Preservadas em Banco de Germoplasma. Rio de Janeiro: UFRJ-IQ. 70p (Tese mestrado).

CHAVARRIAGA-AGUIRRE P; MAYA MM; BONIERBALE MW; KRESOVICH S; FREGENE MA; TOHME J; KOCHERT G. 1998. Microsatellites in cassava (Manihot esculenta): discovery, inheritance and variability. Theoretical Applied Genetics 97: 493-501.

DICE LR. 1945. Measures of the amount of ecological association between species. Ecology 26: 297-307.

DIEGUES AC; ARRUDA RSV. 2001. 07 de outubro de 2010. Saberes tradicionais e biodiversidade no Brasil. Brasília: MMA, Disponível em: <http://www.usp.br/nupaub/ saberes/saberes.htm>

EYZAGUIRRE PB; PADULOSI S; HODGKIN T. 1999. IPGRI's strategy for neglected and underutilized species and the human dimension of agrobiodiversity. In S. Padulosi (ed). Priority-setting for underutilized and neglected plant species of the mediterranean region. International Plant Genetic Resources Institute (IPGRI), Rome.

EXCOFFIER L; LAVAL G; SCHNEIDER S. 2005. Arlequin ver. 3.0: an integrated software package for population genetics data analysis. Evolutionary Bioinformatics Online 1: 47-50.

FAO - Food and Agriculture Organization 2010. Acessado em 21 de março de 2009. Status of World Report II of Plant Genetic Resources for Food and Agriculture, Rome, Italy BIODIVERSITY INTERNATIONAL: BIODIVERSITY INTERNATIONAL Disponivel em: http:// www.bioversityinternational.org.

HOPKINS MS; MITCHELL SE; CASA AM; WANG T; DEAN RE; KOCHERT GD; KRESOVICH S. Discovery and characterization of polymorphic simple sequence repeats (SSRs) in peanut. Crop Science 39: 1243-1247.

INCAPER - Instituto Capixaba de Pesquisa, Assistência Técnica e Extensão Rural. 2010.
Inhame "São Bento. Revista Incaper. Edição Especial, 22.

JIANCCHU X; YONGPING Y; YONGPING P; AYAD WG; EYZAGUIRRE PB. 2001. Genetic diversity in taro (Colocasia esculenta Schott, Araceae) in China: an ethno botanical and genetic approach. Economic Botany 55: 14-31.

KREIKE CM; VAN ECK HJ; LEBOT V. 2004. Genetic diversity of taro, Colocasia esculenta (L.) Schott, in Southeast Asia and the Pacific. Theoretical and Applied Genetics 109: 761 768.

LEBOT V; PRANA MS; KREIKE N; VANHECK $\mathrm{H}$; PARDALES J; OKPUL T; GENDUA T; THONGJJEM M; HUE VIET N; YAP TC. 2004. Characterisation of taro (Colocasia esculenta L.) genetic resources in southeast Asia and Oceania. Genetic Resources Crop Evolution 51: 381-392.

ACE ES; GODWIN ID. 2002. Development and characterisation of polymorphic microsatellite markers in taro, Colocasia esculenta (L.) Schott. Genome 45: 823-832.

MACE ES; MATHUR PN; IZQUIERDO L; HUNTER D; TAYLOR MB; SINGH D; DELACY IH; JACKSON GVH; GODWIN ID. 2006. Rationalization of taro germplasm collections in the Pacific Island region using simple sequence repeat (SSR) markers. Plant Genetic Resources 4: 210-220.

MADEIRA NR; REIFSCHNEIDER FJB; GIORDANO LB. 2008. Contribuição portuguesa à produção e ao consumo de hortaliças no Brasil: uma revisão histórica. Horticultura Brasileira 26: 428-432.

MAPA - MINISTÉRIO DA AGRICULTURA, PECUÁRIA EABASTECIMENTO. Acessado em 20 de dezembro de 2010. Disponível em http://www.agricultura.gov.br/.

NASS LL; VALOIS ACC; MELO IS; VALADARES-INGLIS MC. 2001. Recursos genéticos e melhoramento de plantas, Rondonópolis: Fundação MT, 1183p.

NEI M. 1987. Molecular evolutionary genetics. Columbia University Press, USA.

PUIATTI M. 2002. Manejo da cultura do taro. In: CARMO CAS (ed). Inhame e taro: sistema de produção familiar. Vitória (ES): Incaper, p. 203-252.

OKPUL T; SINGH D; GUNUA T; WAGIH M. 2004. Assessment of diversity using agromorphological traits for selecting acore sample of Papua New Guinea taro (Colocasia esculenta) collection. Genetics Resources Crop 51: 671-678.

RALLO P; DORADO G; MARTIN A. 2000. Development of simple sequence repeats
(SSRs) in olive tree (Olea europaea L.). Theoretical Applied Genetics 101: 984-989.

SARDOS J; NOYER JL; MALAPAR; BOUCHET S; LEBOT V. 2011. Genetic diversity of taro (Colocasia esculenta L. Schott) in Vanuatu (Oceania): an appraisal of the distribution of allelic diversity (DAD) with SSR markers. Genetic Resources Crop Evolution. Online First, 15 July 2011.

SINGH D; MACE ES; GODWIN ID; MATHUR PN; OKPUL T; TAYLOR M; HUNTER D; KAMBUOU R; RAMANATHA RAO V; JACKSON G. 2007. Assessment and rationalization of genetic diversity of Papua New Guinea taro (Colocasia esculenta) using SSR DNA Fingerprinting. Genetic Resources Crop Evolution 55: 811-822.

TANSAO. 2000. Acessado 20 de janeiro de 2011. Annual Report. Taro network for South East Asia and Oceania: Evaluation and breeding for rain-fed cropping systems in South East Asia and Oceania, Port Vila.

TAROGEN. 2001. Acessado 04 de fevereiro de 2011. Taro genetic resources: conservation and utilization Disponível em http://www. spc.int/tarogen.

VAN DE WIEL C; ARENS P; VOSMAN B. 1999. Microsatellite retrieval in lettuce (Lactuca sativa L.). Genome 42: 139-149.

VAN DER SCHOOT J; POSPÍSKOVÁ M; VOSMAN B; SMULDERS MJM. 2000. Development and characterisation of microsatellite markers in black poplar (Populus nigra L.) Theoretical Applied Genetics 101: 317-322.

VIEIRA EA; CARVALHO FIF; OLIVEIRA AC; BENIN G; ZIMMER P; SILVA JAG; MARTINS AF; BERTAN I; SILVA GO; SCHMIDT DAM. 2005. Comparação entre medidas de distância genealógica, morfológica e molecular em aveia em experimentos com e sem a aplicação de fungicida. Bragantia 64: 51-60.

WANG JK. 1983. Introduction. In: WANG JK; HIGA S. (ed). Taro, a review of Colocasia esculenta, and its potentials. Honolulu: University of Hawaii Press, p. 3-13.

ZÁRATE NAH; VIEIRA MC; HIANE PA. 2006a. Produção e composição nutritiva de taro em função do propágulo, em solo hidromórfico do Pantanal Sul-Mato-Grossense. Seminário: Ciências Agrárias 27: 361-366.

ZÁRATE NAH; VIEIRA MC; REGO NH. 2006b. Produtividade de clones de taro em função da população de plantas na época seca do pantanal sul-mato-grossense. Pesquisa agropecuária Tropical 36: 141-143. 